\title{
25. PLIOCENE-PLEISTOCENE PALEOCEANOGRAPHY OF THE NORTH ATLANTIC AT DEEP SEA DRILLING PROJECT SITE 6091
}

\author{
Maureen E. Raymo and William F. Ruddiman, Lamont-Doherty Geological Observatory and Department of \\ Geological Sciences of Columbia University, \\ and \\ Bradford M. Clement, Ocean Drilling Project, Texas A\&M University ${ }^{2}$
}

\begin{abstract}
The Site 609 record of variations in planktonic foraminiferal abundance between 3.5 and 1.0 Ma was examined. Prior to the onset of major Northern Hemisphere glaciation at $2.45 \mathrm{Ma}$, large cyclic variations in North Atlantic hydrography occurred, including a pronounced cooling between 3.4 and $3.2 \mathrm{Ma}$. We interpret this cooling event as a long-term southward displacement of the North Atlantic Drift. Between 2.4 and $2.3 \mathrm{Ma}$, a dramatic change in the foraminiferal fauna, characterized by the disappearances of Neogloboquadrina atlantica and Globorotalia puncticulata and an increased abundance of right-coiling Neogloboquadrina pachyderma, followed the initiation of Northern Hemisphere glaciation. Globorotalia inflata, the evolutionary descendant of Globorotalia puncticulata, was not abundant at this site until $2.1 \mathrm{Ma}$, and left-coiling Neogloboquadrina pachyderma did not become a dominant polar species in this area until 1.7 Ma.
\end{abstract}

\section{INTRODUCTION}

The Quaternary record of planktonic foraminiferal abundance change in the North Atlantic has revealed large fluctuations of sea-surface temperatures (SST) on glacial-interglacial time scales. Changes in the position of surface-water masses and their boundaries, including the Polar Front and the North Atlantic Drift, have been shown to correlate with the expansion and retreat of Northern Hemisphere ice sheets (summarized in Ruddiman and McIntyre, 1984). The record of ice-rafted debris (IRD) in North Atlantic sediments has also been used to trace the history of glaciation, in particular, to date the onset of significant Northern Hemisphere ice growth (Berggren, 1972; Backman, 1979; Poore, 1981). A recent re-evaluation of the initial appearance of IRD in the North Atlantic (Backman, 1979) and new oxygen isotopic data from deep-sea benthic foraminifers (Shackleton et al., 1984) show that a major expansion of continental ice sheets occurred between 2.55 and 2.4 $\mathrm{Ma}$. In this study, we examine planktonic foraminiferal census data from Site 609 to see how North Atlantic surface waters responded to this major climatic event. We also consider the impact of these surface-water changes on the ecologic and evolutionary development of North Atlantic planktonic foraminifers.

Site $609\left(49^{\circ} 52.7^{\prime} \mathrm{N}, 24^{\circ} 14.3^{\prime} \mathrm{W}\right)$ is on the upper middle eastern flank of the Mid-Atlantic Ridge ( $3884 \mathrm{~m}$ water depth) in the region of maximum glacial-interglacial SST change in the late Pleistocene (Ruddiman and McIntyre, 1984). The use of the hydraulic piston corer and

\footnotetext{
${ }^{1}$ Ruddiman, W. F., Kidd, R. B., Thomas, E., et al., Init, Repts, DSDP, 94: Washington (U.S. Govt. Printing Office).

Addresses: (Raymo and Ruddiman) Lamont-Doherty Geological Observatory and Department of Geological Sciences of Columbia University, Palisades, New York 10964; (Clement) Ocean Drilling Program, Texas A\&M University, College Station, Texas 77843.
}

multiple-hole coring have contributed to the almost complete recovery of undisturbed upper Pliocene sediments in this climatically sensitive oceanographic area.

\section{METHODS}

The high-quality paleomagnetic data acquired at Site 609 (Clement and Robinson, this volume) were used to construct a time-depth plot for Holes 609 and 609B (Fig. 1) by correlating the observed polarity reversal sequence with the Geomagnetic Reversal Time Scale (Berggren et al., in press). Accumulation rates estimated by interpolation between magnetic polarity boundaries averaged $7.6 \mathrm{~cm} / \mathrm{kyr}$., with some of the variation due to the approximately $1.5-\mathrm{m}$ uncertainty in placing magnetic boundaries (Clement and Robinson, this volume). To obtain an optimum record of the Quaternary and Pliocene while avoiding disturbed cores in both Holes 609 and 609B, we combined the Hole 609 record from 1.0 to $2.32 \mathrm{Ma}$ with that of Hole 609B from 2.35 to $3.5 \mathrm{Ma}$. By this means, we obtained a 2.5 -m.y. record with one identifiable gap because of the presence of disturbed sediment corresponding to about $30 \mathrm{kyr}$., between 2.35 and $2.32 \mathrm{Ma}$.

Samples were taken at approximately 25 -kyr. intervals, washed in disaggregating solution and wet-sieved through a $63-\mu \mathrm{m}$ sieve. The coarse fraction $(>150 \mu \mathrm{m})$ was then successively split until a random, representative aliquot of roughly 350 specimens was obtained. The planktonic foraminiferal taxa were identified and counted, with generally less than $2 \%$ of each sample population classified as unidentifiable. The presence of benthic foraminifers, ice-rafted mineral grains, and other components such as radiolarians and ostracodes was recorded. One sample, $609-9-5,120-122 \mathrm{~cm}$, consisted almost entirely of IRD with no planktonic foraminifers and was classified as barren.

Planktonic foraminiferal census data were transformed to percentabundance data and an IRD index was calculated using the method of Poore and Berggren (1975). Weight-percent $\mathrm{CaCO}_{3}$ analyses (Ruddiman et al., this volume) are included for comparison (Fig. 2).

\section{RESULTS}

\section{Carbonate Record}

Two carbonate curves for the spliced Site 609 record are plotted in Figure 2. The first curve represents the full-density sampling interval of $30 \mathrm{~cm}$ (corresponding to about 4 kyr., Ruddiman et al., this volume); the second curve represents a subsampled version that includes 


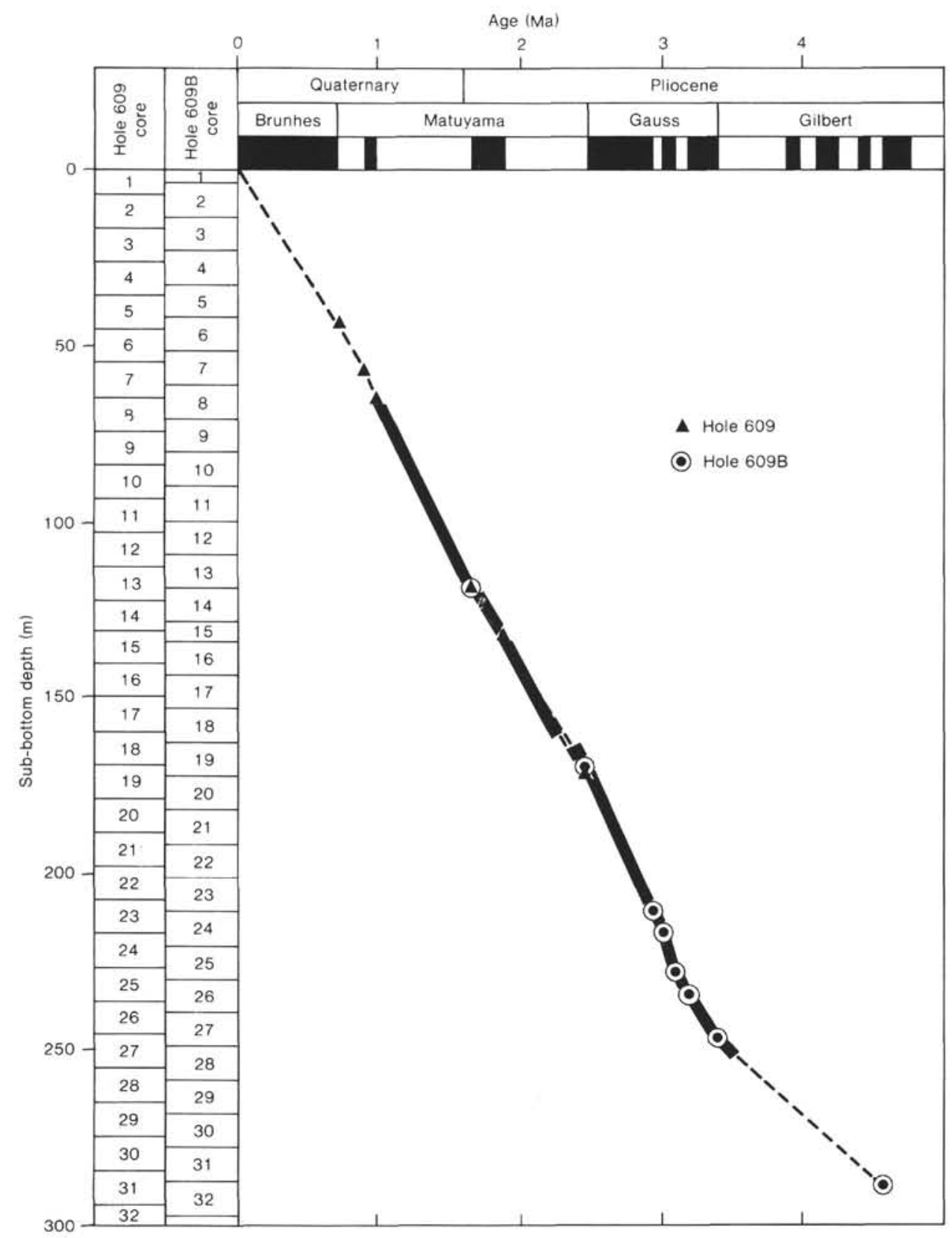

Figure 1. Age-depth plot indicating position at which Holes 609 and $609 \mathrm{~B}$ were spliced. Heavy solid line represents section used in this study. Dashed lines indicate sections not used in this study. See Clement and Robinson (this volume) for table of age-depth correlations.

only those levels for which we have faunal assemblage and IRD counts. The subsampled curve represents an approximate sampling interval of $25 \mathrm{kyr}$., or 150 to 200 $\mathrm{cm}$, depending on the estimated accumulation rates. Both records are shown to demonstrate the aliasing of highfrequency components in a time series if the sampling interval is large relative to the actual information content of the signal. The $25-\mathrm{kyr}$. sampling frequency is higher than that used in many studies of pre-Pleistocene paleoceanography, but it is not sufficient to resolve some of the important features of the $\mathrm{CaCO}_{3}$ record. For instance, between 1.8 and $2.0 \mathrm{Ma}$ several carbonate values fell below $20 \%$, but the aliased record contains no car- bonate values lower than $50 \%$. The aliasing problem should be kept in the mind as a constraint on the interpretation of the following faunal data.

The carbonate record reflects the cumulative effect of productivity, down-slope transport, dissolution, and the presence of noncarbonate material such as IRD and pyrite. Ruddiman et al. (this volume) delineated three intervals with distinctive characteristics. Prior to $3.16 \mathrm{Ma}$, the $\mathrm{CaCO}_{3}$ percentage record shows very minor fluctuations, with values consistently above $88 \%$. From 3.16 to $2.45 \mathrm{Ma}$, carbonate values decreased and variability increased. These lowered values can be attributed in part to the increased presence of pyritized debris in the sam- 


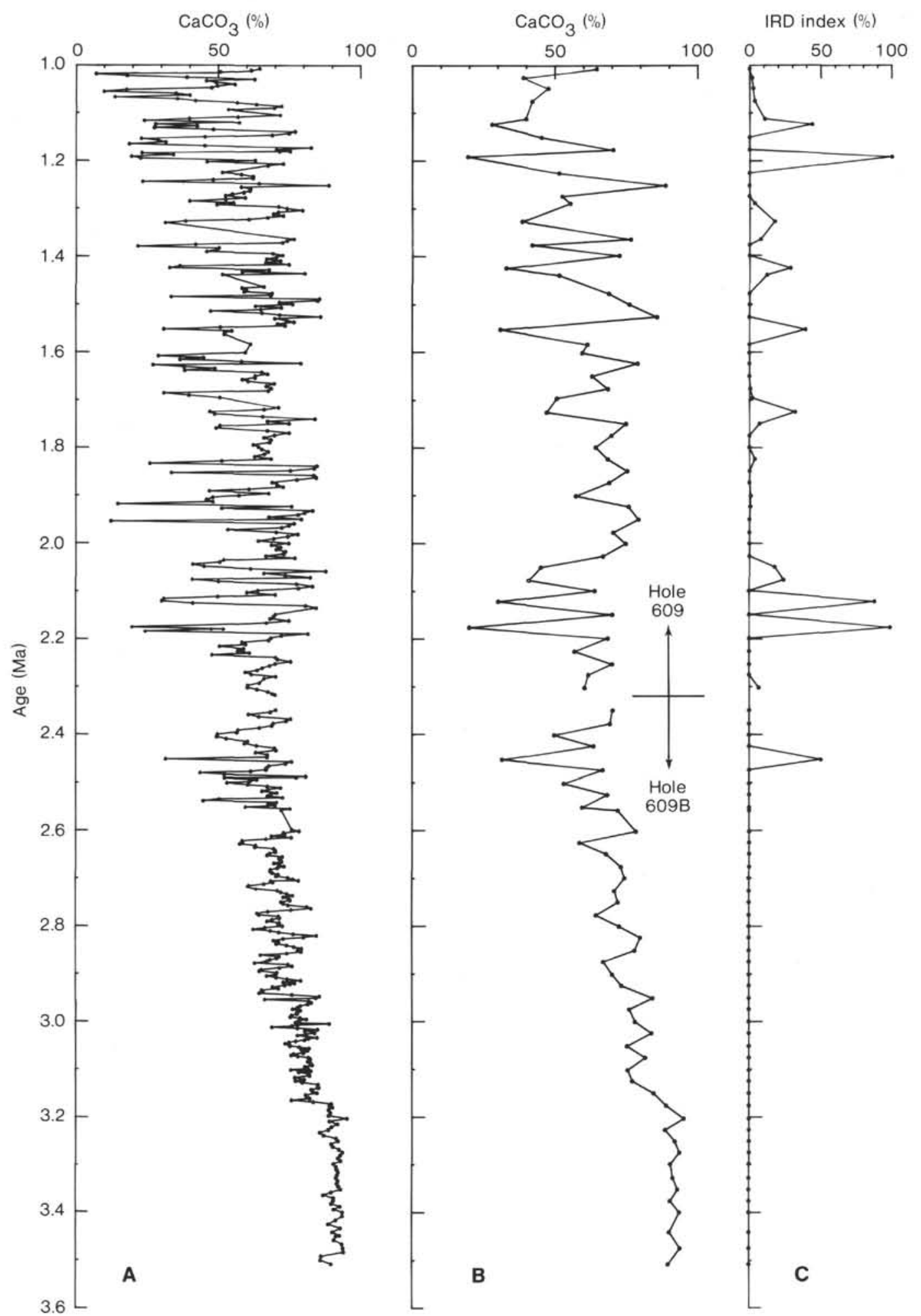

Figure 2. Variations in percent $\mathrm{CaCO}_{3}$ and IRD at Site 609 plotted against time. A. Full 4-kyr. (30-cm) sampling interval; B. 25-kyr. (150 to 200-cm) sampling interval, representing samples for which faunal and IRD data are available; and C. IRD index (after Poore and Berggren, 1975), calculated as: No. ice-rafted mineral grains

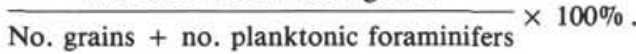


ples but may be controlled largely by increased dissolution. Low carbonate values within this interval are not caused by the presence of IRD.

At $2.45 \mathrm{Ma}, \mathrm{CaCO}_{3}$ percentage values decreased to about $30 \%$, initiating the high-amplitude glacial-interglacial carbonate cycles. This pattern does not appear to have become firmly established until $2.2 \mathrm{Ma}$, but within this interval there is a short section of disturbed sediment ( $<30 \mathrm{kyr}$.) common to both holes that was not examined. After $2.45 \mathrm{Ma}$, the carbonate record correlated inversely with the amount of IRD (Fig. 2), indicating predominantly glacial control of the $\mathrm{CaCO}_{3}$ percentage.

The lowermost occurrence of IRD at Site 609 is in Sample 609B-19-5, 60-62 cm, corresponding to an age of $2.45 \mathrm{Ma}$. No IRD was found in any of the preceding samples, including two low $\mathrm{CaCO}_{3}$ samples (609B-19-6, $120-122 \mathrm{~cm}$ and 609B-20-3, 120-122 cm) at 2.48 and $2.54 \mathrm{Ma}$ in the unaliased record. Thus in basic agreement with Shackleton et al. (1984), we find that $2.45 \mathrm{Ma}$ marked the initiation of extensive calving of icebergs into the eastern subpolar North Atlantic.

\section{Faunal Record}

The relative abundances of the seven most abundant species are plotted against time (Fig. 3) according to the paleomagnetic stratigraphy of Clement and Robinson (this volume). Between 3.5 and $2.4 \mathrm{Ma}$, Neogloboquadrina atlantica (s., or left-coiling), Neogloboquadrina pachyderma (d., or right-coiling), and Globorotalia puncticulata were the three most abundant species. Globigerina bulloides and Globigerinita glutinata were of secondary importance and Neogloboquadrina pachyderma (s.) never made up more than a few percent of the total fauna. Species abundance variations prior to $2.45 \mathrm{Ma}$ were as pronounced as those subsequent to glacial inception, with a rhythmically varying fauna alternately being dominated by $N$. pachyderma (d.), Globorotalia puncticula$t a$, and to a lesser extent $N$. atlantica (s.).

There is evidence of a major modification of the surface water at Site 609 between 3.4 and 3.2 Ma (Fig. 4). Within this interval, G. puncticulata was absent, and $N$. atlantica (s.) reached its highest values $(>39 \%)$ in this record. The maximum in $N$. atlantica (s.) abundance at about 3.3 Ma was preceded and followed by abundance maxima of $N$. pachyderma (d.) at 3.40 and $3.23 \mathrm{Ma}$; these occurred between the outer maxima of $G$. puncticulata, at 3.48 and $3.05 \mathrm{Ma}$, and the central maximum of $N$. atlantica (s.). After an absence of over 0.2 m.y., $G$. puncticulata reappeared at $3.15 \mathrm{Ma}$ and again became a major component of the foraminiferal population.

The next distinctive change in the fauna occurred at $2.4 \mathrm{Ma}$. G. puncticulata disappeared within no more than $25 \mathrm{kyr}$., just after the last in a series of maxima in which it reached 30 to $40 \%$ of the total population. $N$. atlanti$c a$ also disappeared abruptly; the average abundance of Globigerinita glutinata declined; and N. pachyderma (d.) and Globigerina bulloides both increased in abundance at this time. These changes occurred about 0.05 m.y. after the initial appearance of IRD at Site 609.

The subsequent $0.75 \mathrm{~m}$.y. $(2.45-1.7 \mathrm{Ma})$ was a period of evolutionary transition between the preglacial Plio- cene taxa described above and their present-day descendants. N. pachyderma (d.) made up the greatest portion of the fauna through this interval, reaching maximum values of greater than $80 \%$. Globorotalia puncticulata and $N$. atlantica were absent. $G$. inflata, the evolutionary descendant of $G$. puncticulata, did not appear at this site until after 2.15 Ma. Transitional forms between $G$. puncticulata and $G$. inflata were so low in abundance that they did not register in the counted faunal splits.

With the exception of one sample at $2.05 \mathrm{Ma}$, leftcoiling $N$. pachyderma abundances were less than $5 \%$, and large influxes of IRD correlated with maxima of right-coiling $N$. pachyderma. This correlation between maxima of IRD and $N$. pachyderma (d.) is also seen in two samples $(609-15-5,60-62 \mathrm{~cm}$ and 609-15-3, 120-122 $\mathrm{cm})$, which have the lowest carbonate values $(<20 \%)$ in the aliased section between 1.9 and $2.0 \mathrm{Ma}$ (see Fig. 2). In these two samples, $N$. pachyderma (s.) values were $2 \%$ and less than $1 \%$, respectively. $N$. pachyderma (d.) reached values of about $60 \%$, and IRD was abundant. Unlike later in the Pleistocene, high IRD input between 2.4 and $1.7 \mathrm{Ma}$ correlated to abundant right-coiling, rather than left-coiling, $N$. pachyderma.

At $1.7 \mathrm{Ma}, N$. pachyderma (s.) increased dramatically in abundance and began to correlate positively with IRD. The Pleistocene pattern of high-latitude faunal variation characterized by the periodic dominance of leftcoiling $N$. pachyderma during glacial episodes was established at this time. An exception to this pattern is the 0.2 -m.y. interval between 1.3 and $1.1 \mathrm{Ma}$ within which $N$. pachyderma (s.) abundances were extremely low, and right-coiling $N$. pachyderma again reached unusually high abundances in excess of $60 \%$, compared with maximum values of less than $35 \%$ in North Atlantic core tops (Kipp, 1976).

Anomalous faunal abundances have also been found within the interval of 1.3 to $1.1 \mathrm{Ma}$ at Hole 552A (Ruddiman et al., in press). At that hole, the periodically cold climatic conditions evidenced by isotopic and $\mathrm{Ca}-$ $\mathrm{CO}_{3}$ data were not recorded by foraminiferal SST estimates derived from transfer functions. Ruddiman et al. (in press) suggest that this may have been because of a fundamental change in the environmental responses of one or more species. It is also possible that right- and left-coiling $N$. pachyderma respond to an environmental property not directly linked to temperature. The data here indicate that the environment from 1.3 to $1.1 \mathrm{Ma}$ was similar to that between 2.4 and $1.7 \mathrm{Ma}$, a time of evolutionary instability and climatic transition for which we have no modern analogue.

\section{DISCUSSION}

\section{The 3.4-3.2 Ma Cooling Event}

Prior to $2.45 \mathrm{Ma}$, many high-amplitude changes in relative species abundances occurred at Site 609 . Rather than a stable oceanographic regime prior to glaciation, we see evidence of continual variability of the local environment on a scale comparable to the post-2.4 Ma record. Of exceptional interest is the prolonged absence of Globorotalia puncticulata from 3.4 to $3.2 \mathrm{Ma}$ and the 


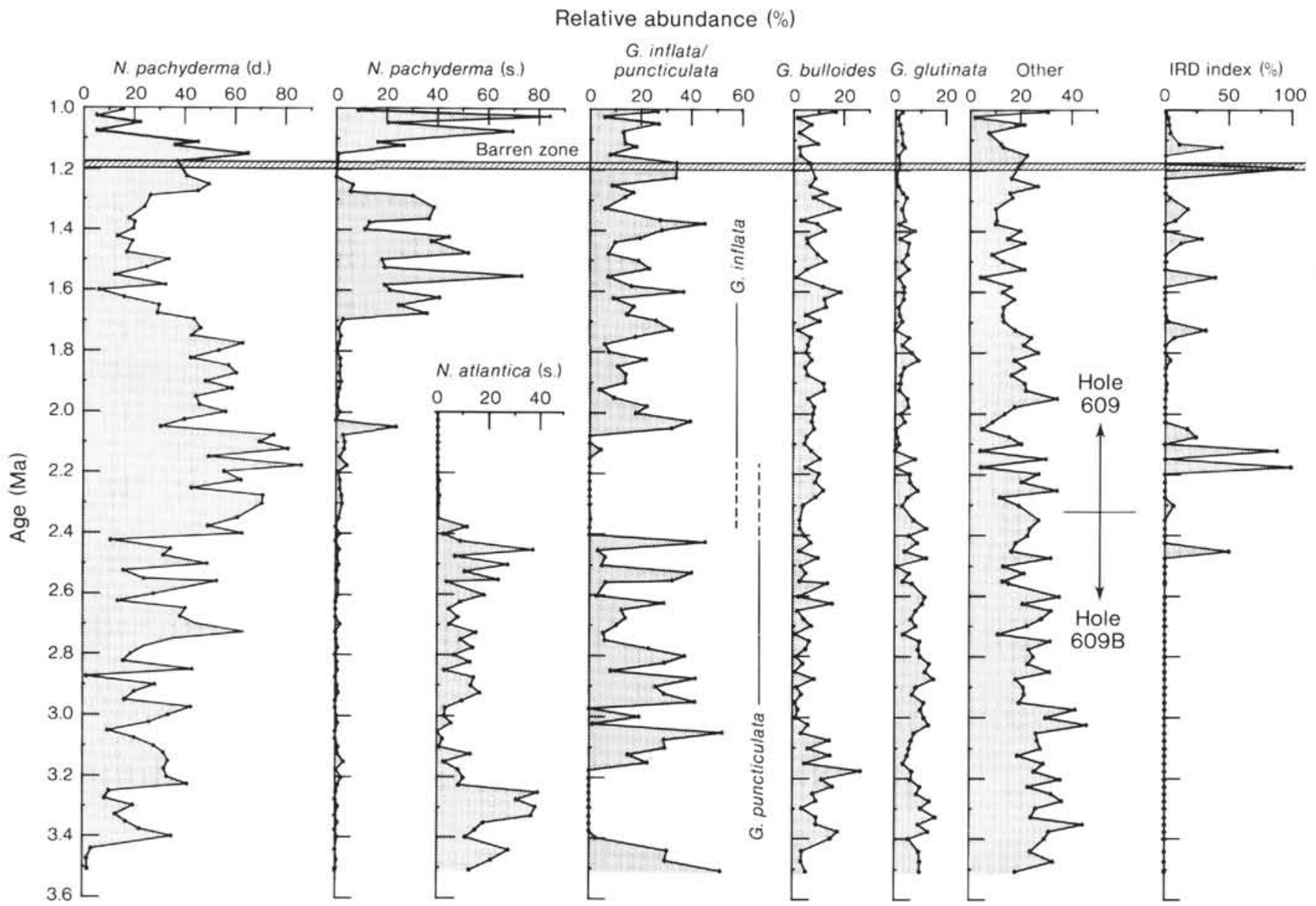

Figure 3. Percent abundance of seven species of planktonic foraminifers at Site 609, with IRD index included for comparison. "Other" category includes less abundant residual species. Neogloboquadrina atlantica (s.) was absent between 2.2 and $1.0 \mathrm{Ma}$, and the period of transition between Globorotalia puncticulata and $G$. inflata is indicated by the overlapping dashed lines. Barren zone contained no planktonic foraminifers and consisted almost entirely of IRD.

maximum in Neogloboquadrina atlantica (s.) abundance at $3.3 \mathrm{Ma}$ (Fig. 4). N. pachyderma (d.) reached abundance maxima at about 3.4 and $3.2 \mathrm{Ma}$. Based on its occurrence in regions of transitional to warm-subtropical waters (Kennett and Srinivasan, 1983), we interpret $G$. puncticulata as the warm end-member of these three species. N. atlantica, which Poore (1981) showed to be more abundant than $N$. pachyderma (d.) at progressively higher latitudes, is interpreted as the cold end-member. $N$. pachyderma $(\mathrm{d}$.) lived in waters transitional in temperature between those preferred by $G$. puncticulata and $N$. atlantica.

Taken together, the abundance records of these three species clearly delineate a surface-water cooling, lasting 0.2 m.y., with the abundance maxima in subpolar $N$. pachyderma (d.) at 3.4 and $3.2 \mathrm{Ma}$ recording the transition into and out of the cooling phase. We interpret this event to represent a long-term southward displacement of the North Atlantic Drift accompanied by cooling in the high-latitude North Atlantic.

A similar event has been identified at Site 548 in the North Atlantic. Moss and Loubere (1984) report the disappearance of G. puncticulata between 3.3 and $3.1 \mathrm{Ma}$. The lack of paleomagnetic control at Site 548 and the diachroneity of biostratigraphic markers at high latitudes (Weaver, this volume) suggest that this event may correlate with the 3.4-3.2 Ma event found at Site 609. Other possible evidence of this episode is the abrupt appearance of G. puncticulata at about 3.1 Ma at Site $606\left(37^{\circ}\right.$ $20.3^{\prime} \mathrm{N}, 35^{\circ} 30.0^{\prime} \mathrm{W}$; Ehrmann and Keigwin, this volume). They interpret $G$. puncticulata as displacing warmer-water species, indicating cooling. This apparent discrepancy could be explained by the northward and southward expansion of the transitional/subtropical water mass that is found between $30^{\circ} \mathrm{N}$ and $50^{\circ} \mathrm{N}$ today (Kipp, 1976).

The linkage of the 3.4-3.2 Ma event to other climatic records from the Northern Hemisphere is not clear. Many investigators have cited evidence of a steplike oxygen isotope increase at 3.2 Ma (Shackleton and Opdyke, 1977; Leonard et al., 1983; Prell, 1984), and several have interpreted this increase as evidence for the initial buildup of ice in the Northern Hemisphere. Moss and Loubere (1984) correlate the cooling event at Site 548 with this presumed ice-growth phase. Alternatively, Prell (1984) has interpreted the isotope record as reflecting a drop in bottom-water temperatures and hence cooling of highlatitude surface waters. However, no evidence is found in the oxygen isotope record of Site 606 for an increase 


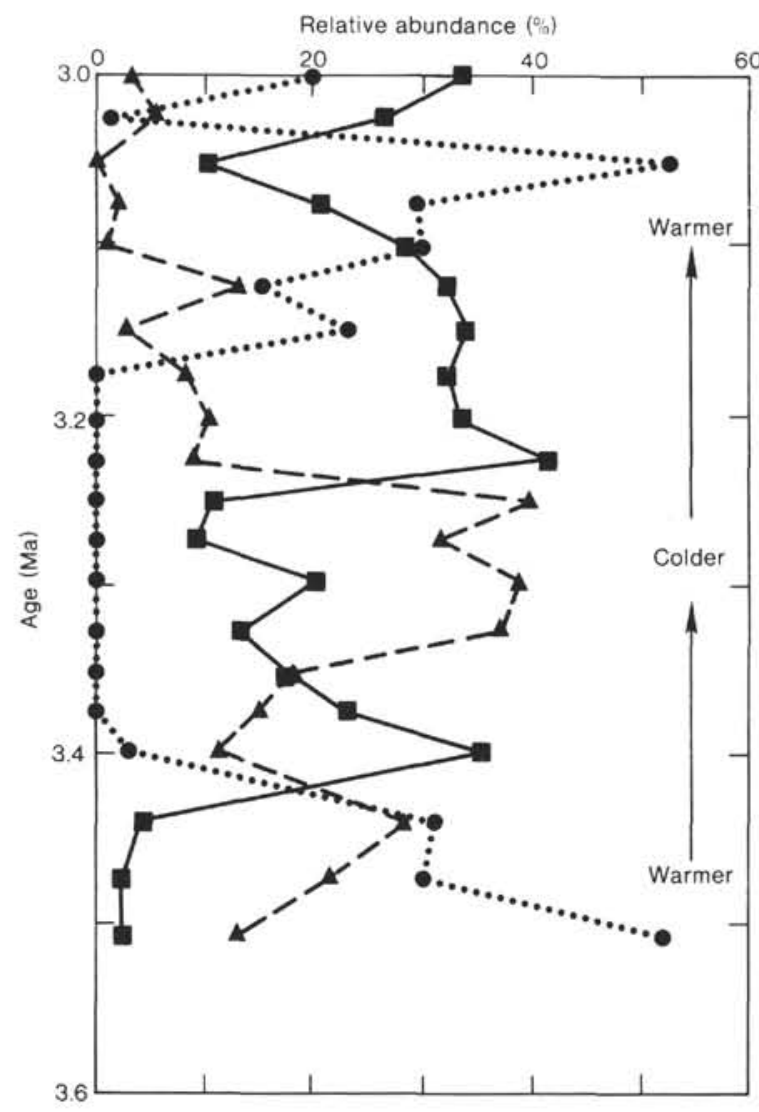

Figure 4. Neogloboquadrina atlantica (s.) -- $\mathbf{\Delta - -}$, Neogloboquadrina pachyderma (d.) - - , and Globorotalia puncticulata $\cdots \cdot .$. abundances between 3.5 and $3.0 \mathrm{Ma}$ in Hole 609B. Generalized sea-surface temperature trend on the right interpreted as northsouth migrations of the North Atlantic Drift.

at 3.2 Ma (Keigwin this volume). We conclude that isotopic evidence for Northern Hemisphere ice accumulation and/or cooling at this time is ambiguous and note that our data point to a North Atlantic warming at 3.2 $\mathrm{Ma}$ rather than cooling.

The earlier North Atlantic temperature decline at 3.4 Ma may have accompanied the inception of glaciation on Iceland, a climatic event involving ice volumes too small to impact the global isotopic signal. The oldest tillites in Iceland are found below what is believed to be the Mammoth reversal (3.08-3.18 Ma), and above a rock originally dated at $3.10 \pm 0.13 \mathrm{Ma}$ (McDougall and Wensink, 1966). Taking into account a recalculation of the radiometric decay constant (Mankinen and Dalrymple, 1979) used to date the underlying rock, the tillite could be older than 3.2 $\mathrm{Ma}$ and thus equivalent to the North Atlantic cooling between 3.4 and $3.2 \mathrm{Ma}$. But it is possible that the reversal just above the tillite is the Kaena (2.92-2.99 Ma) rather than the Mammoth; the Kaena had not been identified in 1966. In this case, the Icelandic glaciation could postdate the oceanic cooling identified here.

Finally, Einarsson et al. (1967) identified an abrupt influx of Pacific boreal mollusks to Iceland at the Gilbert/Gauss magnetic boundary (3.4 Ma). They attribute this influx to migrations over the subsiding Bering land bridge. This migration may have been related to the North Atlantic cooling documented here.

\section{The 2.45 Ma Event}

The initiation of major Northern Hemisphere glaciation at $2.45 \mathrm{Ma}$ profoundly altered the foraminiferal assemblage composition at this North Atlantic site. Globorotalia puncticulata and Neogloboquadrina atlantica, two major components of the preglacial Pliocene fauna, disappeared entirely at this time, while $N$. pachyderma (d.) abundances rose to more than twice those found in the North Atlantic today (Kipp, 1976). The oceanographic factors that caused these changes are not known; oceanic cooling alone appears inadequate as an explanation, because the eliminated species had temperature preferences both warmer and colder than the species that survived the event. Yet it is probable that there was a substantial North Atlantic cooling at that time, in view of the climatic effects likely to be associated with development of major ice sheets (Manabe and Broccoli, 1984). Large-scale Northern Hemisphere glaciation in the late Quaternary has invariably been coupled to significant cooling of the high-latitude North Atlantic Ocean, except for brief northward extensions of the SST lags characteristic of middle latitudes (Ruddiman and McIntyre, 1984).

The explanation of the faunal changes may lie in other oceanographic modifications associated with ice growth. Increased seasonality, altered structure in the shallow parts of the thermocline, and an increased influx of meltwater, sea ice, and icebergs may all have played a role in the dramatic alteration of the North Atlantic fauna at 2.4 $\mathrm{Ma}$. It is premature at this point to choose from among this array of possibilities.

\section{The 2.45-1.7 Ma Interval}

Subsequent to the initiation of glaciation, 0.75 m.y. passed before the planktonic foraminiferal fauna developed the composition characteristic of the late Quaternary, in particular the strong dominance of Neogloboquadrina pachyderma (s.) during glacial conditions. Not until $1.7 \mathrm{Ma}$ did N. pachyderma (s.) become a significant component of the planktonic fauna. To explain the sudden abundance of this species in the late Pliocene North Atlantic, Poore (1981) proposed that climatic fluctuations intensified at this time, resulting in a southward expansion of polar waters. Yet between 2.45 and $1.7 \mathrm{Ma}, \delta^{18} \mathrm{O}$ records suggest significant volumetric variations in Northern Hemisphere ice (Shackleton et al., 1984), and the record of IRD at Site 609 indicates large fluxes of icebergs into this area of the North Atlantic. Thus low abundances of $N$. pachyderma (s.) apparently cannot be attributed to an absence of cold conditions during this interval. A more likely explanation for the sudden predominance of this species may be that an asyet unidentified environmental change directly influenced N. pachyderma (s.) abundances at that time.

The evolutionary transition between Globorotalia puncticulata and $G$. inflata also lies within this interval. The gap between the last appearance of $G$. puncticulata at $2.4 \mathrm{Ma}$ and the abrupt appearance of $G$. inflata at 2.1 
Ma may reflect the time needed for evolutionary adaptation of this lineage to water-mass changes caused by glaciation. Malmgren and Kennett (1981) proposed that increased inflation of the $G$. inflata test allowed this species to adjust to density changes within the water column. These density changes may have been caused by cooling, as Malmgren and Kennett (1981) postulated, or by the buildup of Northern Hemisphere ice, which increased ocean salinity.

\section{CONCLUSIONS}

1. Prior to $2.4 \mathrm{Ma}$, there were many cyclic variations in the surface water hydrography above Site 609 , including a prolonged southward displacement of cooler polar waters between 3.4 and $3.2 \mathrm{Ma}$. An increase in the abundance of Globorotalia puncticulata at $3.2 \mathrm{Ma}$ indicates that the North Atlantic was warming at that time.

2. The initial appearance of IRD at Site 609 occurred at $2.45 \mathrm{Ma}$. At this time, the $\mathrm{CaCO}_{3}$ percentage record began to correlate negatively with IRD abundance and was characterized by the high-amplitude glacial-interglacial variations typical of the Pleistocene.

3. Associated with the large Northern Hemisphere ice buildup at $2.45 \mathrm{Ma}$ was a dramatic change in the composition of the planktonic foraminiferal fauna of the North Atlantic. Within 0.1 m.y., Neogloboquadrina atlantica and $G$. puncticulata disappeared from the record at Site 609 and right-coiling $N$. pachyderma began to dominate the faunal assemblage, reaching abundance values over twice those found in the North Atlantic today.

4. The first appearance of $G$. inflata, the evolutionary descendant of G. puncticulata, occurred at $2.1 \mathrm{Ma}$, and the abrupt increase in the abundance of left-coiling $N$. pachyderma at $1.7 \mathrm{Ma}$ marked the establishment of the typical Pleistocene foraminiferal assemblage in the North Atlantic.

\section{ACKNOWLEDGMENTS}

The authors would like to thank K. Miller, C. Sancetta, K. Karlin, W. Balsam, M. Ledbetter, and E. Thomas for their helpful reviews and comments. This research was supported by NSF Grant OCE8219862. This is Lamont-Doherty Geological Observatory Contribution No. 3986.

\section{REFERENCES}

Backman, J., 1979. Pliocene biostratigraphy of DSDP Sites 111 and 116 from the North Atlantic Ocean and the age of Northern Hemisphere glaciation. Acta Univ. Stockholmiensis, Stockholm, Contrib. Geol., 32(3):115-137.

Berggren, W. A., 1972. Late Pliocene-Pleistocene glaciation. In Laughton, A. S., Berggren, W. A., et al., Init. Repts. DSDP, 12: Washington (U.S. Govt. Printing Office), 953-963.

Berggren, W. A., Kent, D. V., and Van Couvering, J. A., in press. Neogene geochronology and chronostratigraphy. In Snelling, N. J.
(Ed.), Geochronology and the Geology Time Scale. Geol. Soc. London Spec. Publ.

Einarsson. Th., Hopkins, D. M., and Doell, R. R., 1967. The stratigraphy of Tjörnes, Northern Iceland, and the history of the Bering Land Bridge. In Hopkins, D. M. (Ed.), The Bering Land Bridge: Stanford (Stanford University Press), pp. 312-325.

Kennett, J. P., and Srinivasan, S., 1983. Neogene Planktonic Foraminifera: Stroudsburg (Hutchinson Ross Publishing Company).

Kipp, N. G., 1976. New transfer function for estimating past sea-surface conditions from sea-bed distribution of planktonic foraminiferal assemblages in the North Atlantic. In Cline, R. M., Hays, J. D. (Eds.), Investigation of Late Quaternary Paleoceanography and Paleoclimatology, Geol. Soc. Am. Mem., 145:3-41.

Leonard, K. A., Williams, D. F., and Thunell, R. C., 1983. Pliocene paleoclimatic and paleoceanographic history of the South Atlantic Ocean: stable isotopic records from Leg 72 Deep Sea Drilling Project Holes 516A and 517. In Barker, P. F., Carlson, R. L., Johnson, D. A., et al., Init. Repts. DSDP, 72: Washington (U.S. Govt. Printing Office), 895-906.

McDougall, I., and Wensink, H., 1966. Paleomagnetism and geochronology of the Pliocene-Pleistocene lavas in Iceland. Earth Planet. Sci. Lett., 1:232-236.

Malmgren, B. A., and Kennett, J. P., 1981. Phyletic gradualism in a Late Cenozoic planktonic foraminiferal lineage; DSDP Site 284, southwest Pacific. Paleobiology, 7(2):230-240.

Manabe, S., and Broccoli, A. J., 1984. Influence of the CLIMAP ice sheet on the climate of a general circulation model: implications for the Milankovitch theory. In Berger, A. I., Imbrie, J., Hays, J., et al. (Eds.), Milankovitch and Climate (Part 2): Boston (D. Reidel Publishing Company), 789-799.

Mankinen, E. A., and Dalrymple. G. B., 1979. Revised geomagnetic polarity time scale for the interval 0-5 m.y. b.p. J. Geophys. Res., $84: 615-626$.

Moss, K., and Loubere, P., 1984. Response of the North Atlantic to climatic variations in the late Pliocene. Geol. Soc. Am. Abstract with Programs, 16:601. (Abstract)

Poore, R. Z., 1981. Temporal and spatial distribution of ice-rafted mineral grains in Pliocene sediments of the North Atlantic: implications for late Cenozoic climatic history. Soc. Econ. Paleontol. Mineral. Spec. Publ., 32:505-515.

Poore, R. Z., and Berggren, W. A., 1975. Late Cenozoic planktonic foraminiferal biostratigraphy and paleoclimatology of Hatton-Rockall Basin: DSDP Site 116. J. Foraminif. Res., 5:270-293.

Prell, W. L., 1984. Covariance patterns of foraminiferal $\delta^{18} \mathrm{O}$ : an evaluation of Pliocene ice volume changes near 3.2 million years ago. Science, 226:692-694.

Ruddiman, W. F., and McIntyre, A., 1984. Ice-age thermal response and climatic role of the surface Atlantic Ocean, $40^{\circ} \mathrm{N}$ to $63^{\circ} \mathrm{N}$. Geol. Soc. Am. Bull., 95:381-396.

Ruddiman, W. F., Shackleton, N. J., and McIntyre, A., in press. North Atlantic sea-surface temperatures for the last $1.1 \mathrm{~m} . \mathrm{y}$. Geol. Soc. London.

Shackleton, N. J., Backman, J., Zimmerman, H., Kent, D. V., Hall, M. A., Roberts, D. G., Schnitker, D., Baldauf, J. G., Desprairies, A., Homrighausen, R., Huddlestun, P., Keene, J. B., Kaltenback, A. J., Krumsiek, K. A., Morton, A. C., Murray, J. W., and Westberg-Smith, J., 1984. Oxygen isotope calibration of the onset of ice-rafting and history of glaciation in the North Atlantic region. Nature, 307:620-623.

Shackleton, N. J., and Opdyke, N. D., 1977. Oxygen isotope and palaeomagnetic evidence for early Northern Hemisphere glaciation. Nature, 270:216-219.

Date of Initial Receipt: 14 January 1985

Date of Acceptance: 30 June 1985 